\title{
IJCIT
}

(Indonesian Journal on Computer and Information Technology)

Journal Homepage: http://ejournal.bsi.ac.id/ejurnal/index.php/ijcit

\section{Technological Acceptance Model (TAM) Terhadap Adopsi Aplikasi Trading Cryptocurrency Studi Kasus: Indodax Trading Platform}

\author{
Audi Ramadhan ${ }^{1}$, Chandra Indira Septiarani ${ }^{2}$, Faisal Dias ${ }^{3}$, Deden Yoga Pratama ${ }^{4}$ \\ ${ }^{1,2}$ Sistem Informasi, UIN Sunan Ampel Surabaya \\ Surabaya, Indonesia \\ e-mail: audiramadhan29@gmail.com ${ }^{1}$, e-mail: cisrani3@gmail.com² \\ ${ }^{3}$ Manajemen Informatika, Institut Pertanian Bogor \\ Bogor, Indonesia \\ e-mail: faizaldiascaesar19@gmail.com \\ ${ }^{4}$ Manajemen, UPN Veteran Jawa Timur \\ Surabaya, Indonesia \\ e-mail: dedenyogaprat@gmail.com
}

\begin{abstract}
A B S T R A K
Aplikasi trading cryptocurrency merupakan sebuah aplikasi yang relatif baru yang ditandai dengan munculnya banyak cryptocurrency seperti Bitcoin, Ethereum dan lain sebagainya. Oleh sebab itu, analisis penerimaan teknologi pada aplikasi tersebut sangat penting untuk dikaji lebih dalam. Penelitian ini bertujuan untuk menganalisis dan mengukur penerimaan aplikasi trading cryptocurrency yaitu Indodax Trading Platform dengan menggunakan Technology Acceptance Model (TAM) yang diintegrasikan dengan faktor resiko dan kepercayaan. Penelitian ini merupakan penelitian kuantitatif asosiatif dengan menggunakan kuesioner untuk mendapatkan data primer. Sampel yang digunakan pada penelitian ini sebesar 134 dengan menggunakan teknil analisis Semi Equation Model - Partial Least Square (SEM-PLS). Hasil dari penelitian ini yaitu adanya pengaruh dari perceived usefulness dan trust terhadap penggunaan aplikasi trading cryptocurrency. Sedangkan resiko dan perceived ease of use tidak berpengaruh terhadap penggunaan aplikasi trading cryptocurrency.
\end{abstract}

Katakunci: Aplikasi perdagangan Cryptocurrecy, Risk, TAM, Trust

\begin{abstract}
A B S TR A C T S
Cryptocurrency trading application is a relatively new application marked by the emergence of many cryptocurrencies such as Bitcoin, Ethereum and others. Therefore, the analysis of technology acceptance in applications is very important to be researched more deeply. This study aims to analyze and measure the acceptance of cryptocurrency trading application, Indodax Trading Platform using the Technology Acceptance Model (TAM), which is integrating with risk and trust factors. This research is an associative quantitative research using a questionnaire to get primary data. The sample used in this research was 134 using the Semi Equation Model - Partial Least Square (SEM-PLS) analysis model. The results of this study are the effects of perceived usefulness and trust in the use of cryptocurrency trading application. While the risk and perceived ease of use does not affect the use of cryptocurrency trading application.
\end{abstract}

Keywords: Cryptocurrency trading application, Risk, TAM, Trust

1. PENDAHULUAN 
Perkembangan teknologi dewasa ini tak dapat terelekkan lagi. Pesatnya pekembangan teknologi berdampak terhadap semua aspek seperti keuangan misalnya. Contoh dari integrasi dari keuangan dan teknologi adalah cryptocurrency. Cryptocurrency adalah mata uang digital atau virtual yang menggunakan kriptografi untuk tujuan keamanan (Thakur \& Banik, 2018). Kedepannya, Cryptocurrency bisa menjadi salah satu alternatif manusia untuk berinvestasi. Hal ini dikarenakan nominal dari Cryptocurrency relatif meningkat tiap tahunnya dan tidak mengalami inflasi karena jumlahnya yang terbatas. Contoh dari Cryptocurrency adalah Bitcoin, Etherium, Libra dan lain sebagainya. Perdagangan cryptocurrency umumnya dilakukan melalui aplikasi yang telah disediakan oleh pihak ketiga.

Akan tetapi, banyak masyarakat di Indonesia memahami Cryptocurrency sebagai asset untuk investasi dan perdagangan belaka. Hal ini dikarenakan Bank Indonesia dengan peraturan No. 18/40/PBI/2016 memaparkan bahwa Cryptocurrency masih belum bisa digunakan untuk bertransaksi. Pertimbangan tersebut dikarenakan resiko dan tidak adanya jaminan oleh penerbit Cryptocurrency itu sendiri.

Tujuan dari penelitian ini adalah untuk mendeteksi penerimaan dan penggunaan aplikasi trading cryptocurrency oleh masyarakat yang menggunakannya. Penelitian ini menggunakan Technological Acceptance Model (TAM) yang dikembangkan oleh Davis, (1989). TAM hakikatnya memiliki dua konstruk yakni perceived usefulness (PUF) dan perceived ease of use (PEU) yang mempengaruhi behavioral intention to use (BIU). Selain itu, peneliti mempertimbangkan faktor kebaharuan penelitian dengan memasukkan indikator risk dan trust terhadap penelitian ini karena dalam bertransaksi Cryptocurrency, terdapat beberapa resiko seperti capital loss, pencurian data dan kehilangan aset. Oleh sebab itu, faktor kepercayaan pengguna harus mempercayakan aset dan datanya dalam bertransaksi.

Hakikatnya, sebuah teknologi yang diciptakan wajib memiliki manfaat dan nilai guna. Dalam penelitian ini hal tersebut dinarasikan sebagai perceived usefulness. perceived usefulness mengacu pada sejauh mana seseorang percaya bahwa penggunaan teknologi tertentu akan meningkatkan kinerja pekerjaannya (Davis, Bagozzi, \& Warshaw, 1989). Dalam pengukurannya, perceived usefulness memiliki tiga indikator yaitu useful, effectiveness dan productivity. Selain itu, teknologi juga harus memperhatikan aspek perceived ease of use. Dalam penelitian ini perceived ease of use diartikan sebagai kemudahan user dalam menggunakan teknologi tersebut. Dalam literatur lain, perceived ease of use adalah sejauh mana pengadopsi potensial memandang penggunaan teknologi yang dituju menjadi relatif bebas dari usaha (Davis, 1986). Dalam pengukurannya, perceived ease of use dapat dibagi menjadi empat indikeator yakni easy to use, skillful, controllable dan flexibility (Girish, 1994).

Risiko merupakan hal yang tidak dapat dihindari dewasa ini sekalipun dalam sebuah teknologi. Dalam penelitian ini, risiko adalah konsekuensi yang didapat dari sebuah proses yang sedang berlangsung maupun yang akan datang. Dalam penggunaan teknologi, risiko yang mungkin terjadi adalah pencurian data, penyalahgunaan data, perusakan data dan lain sebagainya. Oleh sebab itu peneliti memasukkan risk ( $\mathrm{R})$ dalam penelitian ini. Menurut Lin, Wang, Wang, \& Lu, (2014) terdapat dua jenis risiko yakni risiko security/privacy dan financial.

Selain itu, faktor kepercayaan / trust (T) juga merupakan sebuah hal penting dalam menggunakan teknologi. Dalam penggunaan sebuah teknologi, kepercayaan kepada pihak ketiga sangatlah berpengaruh. User mempercayakan kepada pihak ketiga akan data - datanya yang telah diinput sebelumnya. Menurut Chong, (2013), keamanan dan privasi terkait risiko cenderung lebih tinggi dengan transaksi moneter melalui digital. Oleh sebab itu, sangat penting untuk percaya terhadap pihak ketiga Selain itu, trust juga dapat didefinisikan sebuah keyakinan khusus yang berurusan terutama dengan integritas, kebajikan, dan kemampuan pihak lain (Lee, 2009). Hal ini merupakan salah satu faktor penting mengapa trust menjadi salah satu variabel dalam penelitian ini. Menurut Mayer, Davis, \& Schoorman, (1995), trust memiliki tiga indikator yakni Ability, benevolence dam integrity

Dalam hasil penelitian - penelitian sebelumnya, persepsi manfaat dan persepsi kemudahan penggunaan memiliki pengaruh positif terhadap penerimaan teknologi dan persepsi kemudahan penggunaan memiliki pengaruh positif terhadap persepsi manfaat serta persepsi manfaat juga memediasi antara persepsi kemudahan penggunaan dengan 
penerimaan teknologi (Chen, 2018; Fayad \& Paper, 2015; Harryanto, Muchran, \& Ahmar, 2018; Hartono, Holsapple, Kim, Na, \& Simpson, 2014; Hu, Chau, Sheng, \& Tam, 1999; Jeon \& Park, 2015; Phatthana \& Mat, 2011; Roy, 2017). Selanjutnya terdapat hasil penelitian faktor risk yang berpengaruh positif terhadap penerimaan dan penggunaan sebuah teknologi (Ayo, Mbarika, \& Oni, 2015; Belkhamza \& Wafa, 2009; Juniwati, 2014; Liao, Lin, \& Liu, 2010; Lin et al., 2014). Selain itu, faktor kepercayaan (trust) juga berpengaruh terhadap penerimaan teknologi (Chao, 2019; Jubran, Djamhuri, \& Baridwan, 2016; Paqih, 2011; Sharma \& Sharma, 2019). Sehingga dapat disimpulkan hipotesis sebagai berikut:

$\mathrm{H}_{1}$ : Perceived ease of use memiliki pengaruh positif terhadap behavioral intention to use aplikasi trading cryptocurrency

$\mathrm{H}_{2}$ : Perceived usefulness memiliki pengaruh positif terhadap behavioral intention to use aplikasi trading cryptocurrency

$\mathrm{H}_{3 \text { : }}$ Perceived ease of use memiliki pengaruh positif terhadap perceived usefulness

$\mathrm{H}_{4}$ : Perceived usefulness memediasi antara perceived ease of use dengan behavioral intention to use aplikasi trading cryptocurrency $\mathrm{H}_{5}$ : Risk memiliki pengaruh positif terhadap behavioral intention to use aplikasi trading cryptocurrency

$\mathrm{H}_{6}$ : Trust memiliki pengaruh positif terhadap behavioral intention to use aplikasi trading cryptocurrency

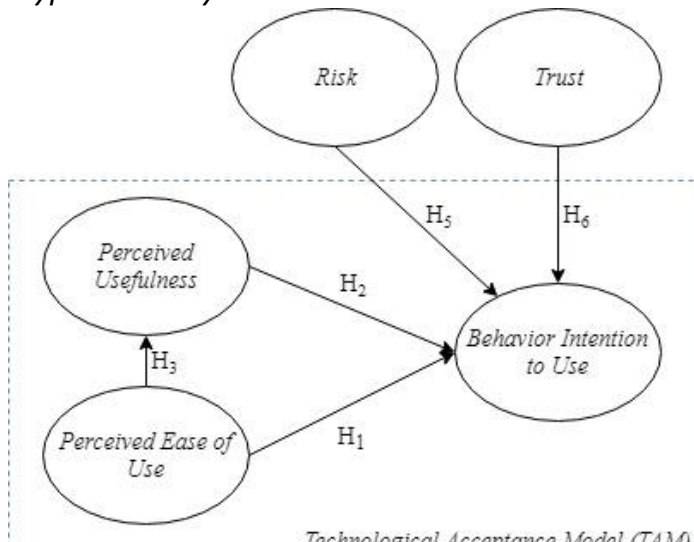

Gambar 1. Kerangka Penelitian

\section{METODE PENELITIAN}

Pada rancangan penelitian ini menggunakan penelitian kuantitatif dengan metode survey yang bersifat eksplanatori dan pengumpulan data primer menggunakan kuesioner. penelitian kuantitatif adalah penelitian empiris yang datanya berbentuk angka - angka (Syahrum \& Salim, 2012). Dimaksudkan dengan penelitian ekspalanori bahwa peneliti menguji, menemukan dan menjelaskan hubungan causal lebih dari dua variabel dengan melalui pengujian hipotesis penelitian. Sebelum melakukan pengujian hipotesis, terlebih dahulu melakukan pengidentifikasian adanya pengaruh antar variabel yang didukung oleh penelitian penelitian terdahulu dengan berdasarkan teori (Neuman, 2011).

Penelitian ini memiliki 5 konstruk dalam pengkurannya yang dinotasikan sebagai PEU, PUF, R, T dan BIU. Masing - masing memiliki pernyataan yang digunakan untuk pengukuran yang mana PEU terdiri dari 3 pernyataan, PUF terdiri dari 3 pernyataan, $\mathrm{R}$ terdiri dari 3 pernyataan, $T$ terdiri dari 4 pernyataan dan BIU terdiri dari 3 pernyataan.

Populasi pada penelitian ini adalah pengguna dari berbagai cryptocurrency. Metode pengambilan sampel menggunakan teknik non probability sampling, dikarenakan setiap aspek yang terdapat dalam populasi tidak memiliki kesempatan atau peluang yang sama untuk dipilih sebagai sampel dan jumlah sampel pada penelitian ini tidak diketahu sehingga teknik yang dipergunakan untuk menentukan ukuran sampel berdasarkan pendekatan Isac Michel, yang memaparkan bahwa minimal jumlah sampel yang harus di ambil sebanyak 57 orang (Siregar, 2013). Berdasarkan teori tersebut, maka jumlah sampel yang digunakan oleh peneliti yaitu sebanyak 134 responden.

Metode yang digunakan peneliti dalam penelitian ini adalah metode survey, dengan menggunakan alat berupa kuesioner. Menurut Sugiyono (2014) kuesioner adalah teknik pengumpulan data yang dilakukan dengan cara memberi seperangkat pernyataan tertulis kepada responden untuk dijawabnya. Metode penyusunan skala menggunakan skala Likert. Variabel yang diukur dalam skala likert dijabarkan kembali kedalam bentuk subvariabel, dimana sub-variabel tersebut dijabarkan kembali menjadi komponenkomponen yang dapat diukur.

Teknik analisis yang dipilih untuk menganalisis data dan menguji hipotesis dalam penelitian ini adalah The Structural Equation Model (SEM). Untuk menjawab hipotesis digunakan Partial Least Square (PLS). PLS merupakan salah satu metode statistika SEM brerbasis varian yang didesain untuk 
menyelesaikan regresi berganda ketika terjadi permasalahan spesifik pada data, seperti ukuran sampel penelitian kecil, adanya data yang hilang (missing values) dan multikolinieritas (Jogiyanto \& Abdillah, 2009).

Tabel 1. Pengukuran Variabel

\begin{tabular}{|c|c|c|}
\hline Variabel & Kode & Sumber \\
\hline $\operatorname{PEU}\left(\mathrm{X}_{1}\right)$ & $\begin{array}{l}\text { PEU1 } \\
\text { PEU2 } \\
\text { PEU3 }\end{array}$ & 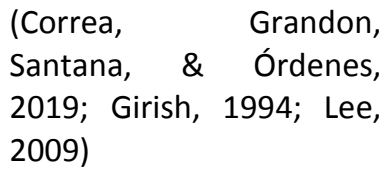 \\
\hline $\operatorname{PUF}\left(\mathrm{X}_{2}\right)$ & $\begin{array}{l}\text { PUF1 } \\
\text { PUF2 } \\
\text { PUF3 }\end{array}$ & $\begin{array}{l}\text { (Davis, 1989; Lee, 2009; } \\
\text { Weng, Yang, Ho, \& Su, } \\
\text { 2018) }\end{array}$ \\
\hline$R\left(\mathrm{X}_{3}\right)$ & $\begin{array}{l}\text { R1 } \\
\text { R2 } \\
\text { R3 }\end{array}$ & $\begin{array}{l}\text { (Lee, 2009; Lin et al., } \\
2014 ; \quad \text { Littler } \\
\text { Melanthiou, 2006) }\end{array}$ \\
\hline$T\left(\mathrm{X}_{4}\right)$ & $\begin{array}{l}\text { T1 } \\
\text { T2 } \\
\text { T3 } \\
\text { T4 }\end{array}$ & $\begin{array}{l}\text { (Gefen, Karahana, \& } \\
\text { Starub, 2003; Lee, 2009; } \\
\text { Xie, Song, Peng, \& } \\
\text { Shabbir, 2017) }\end{array}$ \\
\hline BIU (Y) & $\begin{array}{l}\text { BIU1 } \\
\text { BIU2 } \\
\text { BIU3 }\end{array}$ & $\begin{array}{l}\text { (Lee, 2009; Pavlou, 2003; } \\
\text { Rana, Dwivedi, Percy, \& } \\
\text { Williams, 2014) }\end{array}$ \\
\hline
\end{tabular}

\section{HASIL DAN PEMBAHASAN}

\subsection{Deskripsi Responden}

Penelitian ini bertujuan untuk menguji penerimaan pengguna aplikasi trading cryptocurrency XYZ Trading Platform dengan sampel pengguna berjumlah 134 orang. Penyusunan responden berdasarkan demografi tertentu seperti jenis kelamin, latar belakang usia dan pendapatan (Venkatesh, Aloysius, Hoehle, \& Burton, 2017).

Tabel 2.

Deskripsi Responden Berdasarkan Jenis Kelamin

\begin{tabular}{ccc}
\hline Jenis Kelamin & $\mathrm{N}$ & Persentase \\
\hline Laki - Laki & 103 & $77 \%$ \\
Perempuan & 31 & $23 \%$ \\
\hline
\end{tabular}

Hasil data responden dari pengisian kuesioner, menunjukkan bahwa pengguna aplikasi trading cyptocurrency didominasi oleh jenis kelamin laki - laki dengan persentase sebesar 77\%, sedangkan pengguna berjenis kelamin perempuan hanya sebesar $23 \%$ saja.
Tabel 3.

Deskripsi Responden Berdasarkan Pekerjaan

\begin{tabular}{ccc}
\hline Pekerjaan & $\mathrm{N}$ & Persentase \\
\hline $\begin{array}{c}\text { Pelajar/ } \\
\text { Mahasiswa } \\
\text { Pegawai }\end{array}$ & 62 & $46 \%$ \\
$\begin{array}{c}\text { Swasta } \\
\text { PNS/TNI/ }\end{array}$ & 20 & $15 \%$ \\
$\quad$ Polri & 4 & $3 \%$ \\
$\begin{array}{c}\text { Wirausaha } \\
\text { Lainnya }\end{array}$ & 35 & $26 \%$ \\
\hline & 13 & $10 \%$ \\
\hline
\end{tabular}

Hasil data responden dari pengisian kuesioner, menunjukkan bahwa pengguna aplikasi trading cyptocurrency didominasi oleh kalangan pelajar/mahasiswa dengan persentase sebesar 46\%. Selain itu diikuti dengan wirausahawan sebesar 26\%, pegawai swasta sebesar $15 \%$, lain - lain (ibu rumah tangga, $\mathrm{PHL}$ dan lain sebagainya) sebesar $10 \%$ dan PNS/TNI/ Polri sebesar $3 \%$.

Tabel 4. Deskripsi Responden Berdasarkan Usia

\begin{tabular}{ccc}
\hline Usia & $\mathrm{N}$ & Persentase \\
\hline$<18$ & 17 & $13 \%$ \\
$18<25$ & 83 & $62 \%$ \\
$26<35$ & 31 & $23 \%$ \\
$>35$ & 3 & $2 \%$ \\
\hline
\end{tabular}

Hasil data responden dari pengisian kuesioner, menunjukkan bahwa pengguna aplikasi trading cyptocurrency didominasi oleh pengguna berumur kisaran 18 hingga 25 tahun dengan persentase sebesar $62 \%$. Sisanya adalah pengguna dengan umur kisaran 26 hingga 35 tahun sebanyak 23\%, kurang dari 18 tahun sebanyak $13 \%$ dan lebih dari $35 \%$ hanya sebesar $2 \%$.

Tabel 5. Deskripsi Responden Berdasarkan Pendapatan dari Trading per Bulan

\begin{tabular}{ccc}
\hline Pendapatan & $\mathrm{N}$ & Persentase \\
\hline$<1.000 .000$ & 66 & $49 \%$ \\
$1.000 .000<$ & 41 & $31 \%$ \\
4.000 .000 & & \\
$>4.000 .000$ & 27 & $20 \%$ \\
\hline
\end{tabular}

Hasil data responden dari pengisian kuesioner, menunjukkan bahwa pengguna 
aplikasi trading cyptocurrency didominasi oleh pengguna dengan pendapatan hasil trading dengan nominal dibawah 1 juta per bulan dengan persentase sebesar $49 \%$. Selanjutnya pengguna dengan pendapatan hasil trading sebesar 1 juta hingga 4 juta rupiah perbulan sebanyak $31 \%$ dan yang terakhir adalah pengguna dengan hasil pendapatan dari trading perbulan lebih dari 4 juta dengan persentase sebanyak $20 \%$.

\subsection{Hasil Analisis Data}

3.2.1 Evaluasi Model Pengukuran (Outer Model)

Evaluasi model pengukuran terdiri dari tiga tahap yakni uji validitas konvergen, uji validitas diskriminan dan uji reliabilitas komposit. Validitas konvergen diukur berdasarkan kriteria bahwan koefisien estimasi indikator yang signifikan pada faktor konstruk, sedangkan validitas diskriminan diukur berdasarkan korelasi kuadrat antara variabel dengan variabel lainnya tidak bersifat unidimensional (Wu \& Chen, 2017). Evaluasi skala pengukuran dapat dikatakan valid jika semua item factor loadings dan composite reliability (CR) memiliki nilai lebih dari 0.7 dan nilai average variance extracted (AVE) lebih dari 0.5 (Fornell \& Larcker, 1981).

Hasil uji validitas konvergen pada tabel 6 menunjukkan bahwa semua nilai factor loadings memiliki nilai lebih dari 0.7 dan nilai factor loadings indikator lebih besar daripada nilai variabel lain, sehingga dapat dismpulkan bahwa seluruh indikator yang diterapkan pada penelitian ini adalah valid.

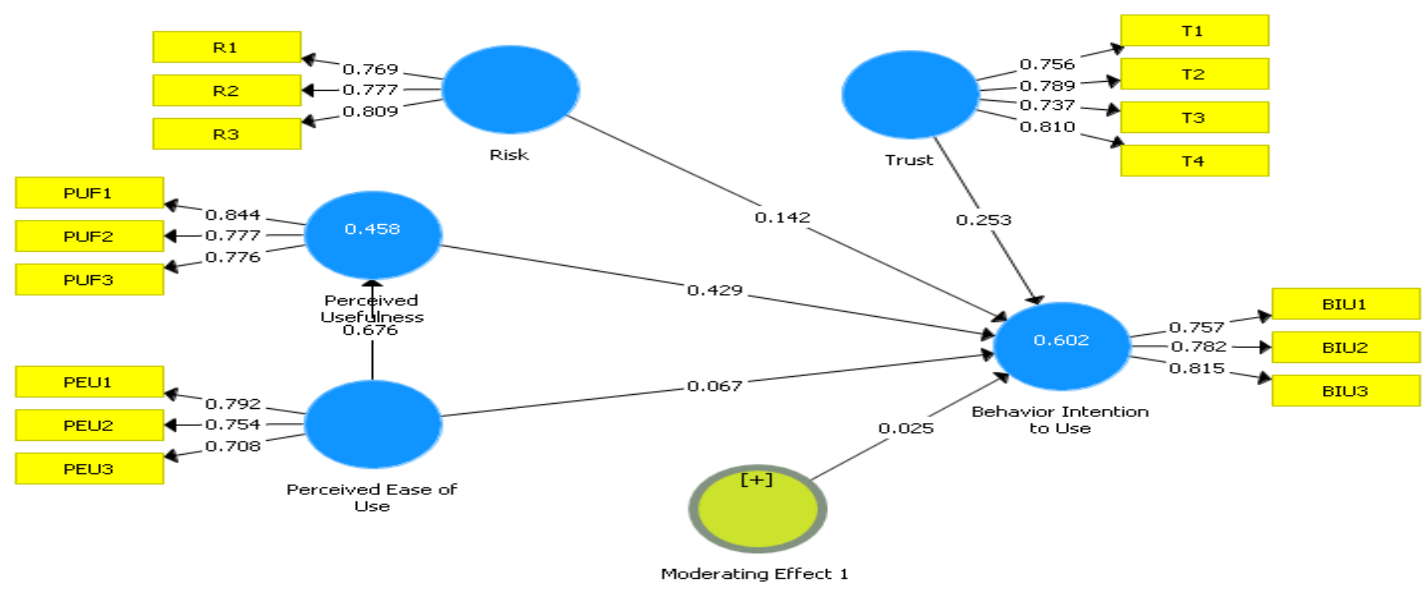

Gambar 2. Hasil Analisis Jalur SmartPLS 3.0

Tabel 6. Hasil Uji Validitas Konvergen

\begin{tabular}{cccccc}
\hline Item & PEU & PUF & R & T & BIU \\
\hline PEU1 & $\mathbf{0 . 7 9 2}$ & 0.504 & 0.440 & 0.480 & 0.457 \\
PEU2 & $\mathbf{0 . 7 5 4}$ & 0.568 & 0.385 & 0.491 & 0.411 \\
PEU3 & $\mathbf{0 . 7 0 8}$ & 0.450 & 0.573 & 0.494 & 0.479 \\
PUF1 & 0.566 & $\mathbf{0 . 8 4 4}$ & 0.488 & 0.583 & 0.661 \\
PUF2 & 0.481 & $\mathbf{0 . 7 7 7}$ & 0.536 & 0.530 & 0.531 \\
PUF3 & 0.570 & $\mathbf{0 . 7 7 6}$ & 0.511 & 0.565 & 0.547 \\
R1 & 0.539 & 0.552 & $\mathbf{0 . 7 6 9}$ & 0.651 & 0.436 \\
R2 & 0.446 & 0.415 & $\mathbf{0 . 7 7 7}$ & 0.361 & 0.451 \\
R3 & 0.474 & 0.532 & $\mathbf{0 . 8 0 9}$ & 0.453 & 0.530 \\
T1 & 0.497 & 0.468 & 0.428 & $\mathbf{0 . 7 5 6}$ & 0.496 \\
T2 & 0.507 & 0.547 & 0.440 & $\mathbf{0 . 7 8 9}$ & 0.455 \\
T3 & 0.463 & 0.569 & 0.526 & $\mathbf{0 . 7 3 7}$ & 0.455 \\
T4 & 0.536 & 0.652 & 0.510 & $\mathbf{0 . 8 1 0}$ & 0.649 \\
BIU1 & 0.467 & 0.563 & 0.508 & 0.555 & $\mathbf{0 . 7 5 7}$ \\
BIU2 & 0.483 & 0.536 & 0.443 & 0.535 & $\mathbf{0 . 7 8 2}$ \\
BIU3 & 0.455 & 0.615 & 0.472 & 0.506 & $\mathbf{0 . 8 1 5}$ \\
\hline
\end{tabular}

Tabel 7. Hasil Uji Validitas Diskriminan

\begin{tabular}{lccccc}
\hline & BIU & PEU & PUF & R & T \\
\hline BIU & $\mathbf{0 . 7 8 5}$ & & & & \\
PEU & 0.597 & $\mathbf{0 . 7 5 2}$ & & & \\
PUF & 0.729 & 0.676 & $\mathbf{0 . 8 0 0}$ & & \\
R & 0.605 & 0.617 & 0.637 & $\mathbf{0 . 7 8 5}$ & \\
T & 0.678 & 0.649 & 0.700 & 0.616 & $\mathbf{0 . 7 7 4}$ \\
\hline
\end{tabular}

Hasil uji validitas diskriminan pada tabel 7 mengindikasikan bahwa variabel laten memiliki nilai AVE lebih besar $\mathrm{R}^{2}$ dari pada variabel laten yang lainnya. Sehingga dapat dikatakan bahwa variabel ditinjau dari hasil uji validitas diskriminan pada penelitian ini valid. 
Tabel 8. Hasil Uji Reliabilitas Variabel Laten

\begin{tabular}{lccc}
\hline Variabel & $\begin{array}{c}\text { Composite } \\
\text { Reliability }\end{array}$ & AVE & Status \\
PEU & .796 & .565 & Reliabel \\
PUF & .842 & .639 & Reliabel \\
$R$ & .828 & .617 & Reliabel \\
$T$ & .856 & .598 & Reliabel \\
BIU & .838 & .616 & Reliabel \\
\hline
\end{tabular}

Hasil uji reliabilitas pada tabel 8 menunjukkan bahwa pemuatan variabel seperti nilai AVE dan CR melebihi nilai ambang batas yang disarankan yakni 0.5 dan 0.7 sehingga seluruh variabel yang terdapat pada penelitian ini dapat dikatakan reliabel.

\subsubsection{Evaluasi Model Struktural (Inner Model)}

Tabel 9. Hasil Uji Signifikansi

\begin{tabular}{lccc}
\hline & $\begin{array}{c}\text { Original } \\
\text { Sample }\end{array}$ & $\begin{array}{c}\mathrm{T} \\
\text { Statictics }\end{array}$ & P Values \\
\hline PEU $\rightarrow$ BIU & 0.067 & 0.630 & 0.529 \\
PEU $\rightarrow$ & 0.676 & 12.836 & 0.000 \\
PUF & & & \\
PUF $\rightarrow$ BIU & 0.429 & 3.559 & 0.000 \\
$R \rightarrow$ BIU & 0.142 & 1.457 & 0.146 \\
$T \rightarrow$ BIU & 0.253 & 2.298 & 0.022 \\
\hline
\end{tabular}

Pada tabel 9 memaparkan tentang pengujian hipotesis dimana hasil yang didapat menjelaskan tentang penolakan atau penerimaannya. Perceived ease of use terhadap behavioral intention to use memiliki nilai $\mathrm{P}$ sebesar 0.529 dengan nilai t-statistik 0.630. Hal tersebut membuktikan bahwa perceived ease of use tidak memiliki pengaruh terhadap behavioral intention to use. Sebaliknya, Perceived ease of use terhadap perceived usefulness memiliki nilai $P$ sebesar 0.000 dengan nilai T-statistik 12.836. hal tersebut menandakan bahwa Perceived ease of use memiliki pengaruh signifikan terhadap perceived usefulness. Selain itu terdapat perceived usefulness terhadap behavioral intention to use memiliki nilai $\mathrm{P} 0.000$ dan t-statistik sebesar 3.559. Oleh sebab itu, perceived usefulness memiliki pengaruh positif terhadap behavioral intention to use. Selanjutnya adalah risk dan trust terhadap behavioral intention to use dimana masing masing memiliki nilai $P 0.146$ dan 0.022 dengan nilai t-statistik 1.457 dan 2.298. dengan demikian, risk tidak memiliki pengaruh positif terhadap behavioral intention to use sedangkan trust memiliki pengaruh positif terhadap behavioral intention to use.

Tabel 10. Indirect Effect

\begin{tabular}{lccc}
\hline & $\begin{array}{c}\text { Original } \\
\text { Sample }\end{array}$ & $\begin{array}{c}\mathrm{T} \\
\text { Statictics }\end{array}$ & P Values \\
\hline PEU $\rightarrow$ & 0.290 & 3.469 & 0.001 \\
PUF $\rightarrow$ BIU & & & \\
\hline
\end{tabular}

Pada tabel 10 menjelaskan pengaruh secara tidak langsung dari perceived ease of use terhadap behavioral intention to use yang dimediasi oleh perceived usefulness. Masing masing nilai $\mathrm{P}$ dan t-statistik memiliki nilai sebesar 0.001 dan 3.469. Sehingga dapat ditarik kesimpulan bahwa perceived usefulness memediasi antara perceived ease of use dengan behavioral intention to use. Dengan demikian dapat disimpulkan hasil pengujian hipotesis sebagai berikut:

Tabel 11. Hasil Pengujian Hipotesis

\begin{tabular}{cll}
\hline Hipotesis & Keterangan & \multicolumn{1}{c}{ Status } \\
\hline $\mathrm{H}_{1}$ & PEU $\rightarrow$ BIU & Ditolak \\
$\mathrm{H}_{2}$ & PEU $\rightarrow$ PUF & Diterima \\
$\mathrm{H}_{3}$ & PUF $\rightarrow$ BIU & Diterima \\
$\mathrm{H}_{4}$ & PIU $\rightarrow$ PUF $\rightarrow$ & Diterima \\
& BIU & \\
$\mathrm{H}_{5}$ & $\mathrm{R} \rightarrow$ BIU & Ditolak \\
$\mathrm{H}_{6}$ & $\mathrm{~T} \rightarrow$ BIU & Diterima \\
\hline
\end{tabular}

\section{KESIMPULAN}

Aplikasi trading cryptocurrency merupakan aplikasi yang relatif baru sehingga perlu adanya pengukuran penerimaan dari aplikasi tersebut. Dari hasil pembahasan dan analisis pada penelitian ini, dapat disimpulkan beberapa hal.

Pertama, perceived ease of use tidak memiliki pengaruh terhadap behavioral intention to use dari aplikasi trading tersebut. Hal ini disimpulkan bahwa kemudahan penggunaan dari aplikasi tersebut tidak menjadi faktor penentu dalam penerimaan aplikasi tersebut.

Kedua, perceived usefulness memiliki pengaruh signifikan terhadap behavioral intention to use. Faktor ini dapat menjadi acuan bahwa pengguna lebih mementingkan manfaat dari penggunaan aplikasinya daripada kemudahan dalam menggunakannya.

Ketiga, Perceived ease of use memiliki pengaruh signifikan terhadap perceived usefulness. Hal ini dikarenakan kemudahan 
dapat menajadi sebuah manfaat dalam menggunakan aplikasi.

Keempat, perceived usefulness memediasi antara perceived ease of use dengan behavioral intention to use. Hal tersebut menyatakan bahwa kemudahan pada dasarnya bisa menjadi manfaat tersendiri dalam menggunakan aplikasi tersebut.

Kelima, risk tidak memiliki pengaruh terhadap behavioral intention to use. Hal ini disebabkan user mengesampingkan hal yang tidak terjadi secara langsung dalam menggunakan aplikasi.

Keenam, trust memiliki pengaruh positif terhadap behavioral intention to use. Dengan demikian, kepercayaan antara user dengan pengembang dapat menjadi landasan untuk penerimaan teknologi.

Selain itu, penelitian ini memiliki beberapa batasan yang diharapkan dapat dilakukan pada penelitian selanjutnya. Penelitian ini masih menggunakan TAM dengan versi pertama, sehingga penelitian selanjutnya dapat dilakukan dengan model - model penerimaan teknologi yang lain. Selain itu, penambahan variabel variabel lain sangat perlu untuk dilakukan. Dengan demikian teori penerimaan teknologi dapat terus berkembang seiring dengan perkembangan zaman dan teknologi.

\section{REFERENSI}

Ayo, C. K., Mbarika, V. W., \& Oni, A. A. (2015). The Influence of Trust and Risk on Intention to Use E-Democracy in Nigeria. Mediterranean Journal of Social Sciences, 6(6), 477-486. https://doi.org/10.5901/mjss.2015.v6n6s $1 \mathrm{p} 477$

Belkhamza, Z., \& Wafa, S. A. (2009). The Effect of Perceived Risk on the Intention to Use E-commerce: The Case of Algeria. Journal of Internet Banking and Commerce, 14(1).

Chao, C. (2019). Factors Determining the Behavioral Intention to Use Mobile Learning: An Application and Extension of the UTAUT Model. Front. Psychol, 10, 1652.

https://doi.org/10.3389/fpsyg.2019.0165 2

Chen, J. K. (2018). The influence of behavioural intention on third-party e-commerce payment. South African Journal of Economic and Management Sciences, 21(1), 1-9.
Chong, A. Y. (2013). A two-staged SEM-neural network approach for understanding and predicting the determinants of $\mathrm{m}$ commerce adoption. Expert Systems With Applications, 40(4), 1240-1247. https://doi.org/10.1016/j.eswa.2012.08.0 67

Correa, P. R., Grandon, E. E., Santana, M. R., \& Órdenes, L. B. (2019). Explaining the Use of Social Network Sites as Seen by Older Adults : The Enjoyment Component of a Hedonic Information System. International Journal of Environmental Research and Public Health, 16(10), 1673.

Davis, F. D. (1986). A TECHNOLOGY ACCEPTANCE MODEL FOR EMPIRICALLY TESTING NEW END-USER INFORMATION SYSTEMS: THEORY AND RESULTS.

Davis, F. D. (1989). Perceived Usefulness, Perceived Ease of Use, and User Acceptance of Information Technology. MIS Quarterly, 13(3), 319-340. https://doi.org/10.2307/249008

Davis, F. D., Bagozzi, R. P., \& Warshaw, P. R. (1989). User Acceptance of Computer Technology: A Comparison of Two Theoretical Models. Management Science, 35(8), 982-1003. https://doi.org/10.1287/mnsc.35.8.982

Fayad, R., \& Paper, D. (2015). The Technology Acceptance Model E-Commerce Extension: A Conceptual Framework. Procedia Economics and Finance, 26, 1000-1006.

https://doi.org/10.1016/S22125671(15)00922-3

Fornell, C., \& Larcker, D. F. (1981). Evaluating Structural Equation Models with Unobservable Variables and Measurement Error. Journal of Marketing Research, 18(1), 39-50.

Gefen, D., Karahana, E., \& Starub, D. W. (2003). TRUST AND TAM IN ONLINE SHOPPING: AN INTEGRATED MODEL. MIS Quarterly, 27(1), 51-90.

Girish, H. (1994). A replication of perceived usefulness and perceived ease of. Decision Sciences, 25(5/6), 863-874.

Harryanto, Muchran, M., \& Ahmar, A. S. (2018). Application of TAM model to the use of information technology. International Journal of Engineering \& Technology, 7(2.9), 37-40.

Hartono, E., Holsapple, C. W., Kim, K., Na, K., \& Simpson, J. T. (2014). Measuring 
perceived security in $\mathrm{B} 2 \mathrm{C}$ electronic commerce website usage: A respeci fi cation and validation. Decision Support Systems, 62, 11-21. https://doi.org/10.1016/j.dss.2014.02.00 6

Hu, P. J., Chau, P. Y. K., Sheng, O. R. L., \& Tam, K. Y. (1999). The Technology Examining Acceptance Model Using Physician of Acceptance Telemedicine Technology. Journal of Management Information Systems, 16(2), 91-112.

Jeon, E., \& Park, H. (2015). Factors Affecting Acceptance of Smartphone Application for Management of Obesity. Healthcare Infotmatics Research, 21(2), 74-82.

Jogiyanto, H., \& Abdillah, W. (2009). Konsep dan Aplikasi PLS (Partial Least Square) untuk Penelitian Empiris (I). Yogyakarta: BPFE.

Jubran, D., Djamhuri, A., \& Baridwan, Z. (2016). THE INTENTION TO USE E-GOVERNMENT SYSTEM (E-EXPORTING) IN SHIPPING AND EXPORTING COMPANY IN LIBYA. The International Journal of Accounting and Business Society, 24(2), 13-34.

Juniwati. (2014). Influence of Perceived Usefulness, Ease of Use, Risk on Attitude and Intention to Shop Online. European Journal of Business and Management, 6(27), 218-229.

Lee, M. (2009). Predicting and explaining the adoption of online trading : An empirical study in Taiwan. Decision Support Systems, 47(2), 133-142. https://doi.org/10.1016/j.dss.2009.02.00 3

Liao, C., Lin, H., \& Liu, Y. (2010). Predicting the Use of Pirated Software: A Contingency Model Integrating Perceived Risk with the Theory of Planned Behavior. Journal of Business Ethics, 91, 237-252. https://doi.org/10.1007/s10551-0090081-5

Lin, J., Wang, B., Wang, N., \& Lu, Y. (2014). Understanding the evolution of consumer trust in mobile commerce: a longitudinal study. Information Technology and Management, 15(1), 37-49. https://doi.org/10.1007/s10799-0130172-y

Littler, D., \& Melanthiou, D. (2006). Consumer perceptions of risk and uncertainty and the implications for behaviour towards innovative retail services: The case of Internet Banking. Journal of Retailing and
Consumer Services, 13(6), 431-443. https://doi.org/10.1016/j.jretconser.2006 .02 .006

Mayer, R. C., Davis, J. H., \& Schoorman, F. D. (1995). AN INTEGRATIVE MODEL OF ORGANIZATIONAL TRUST. Academy of Management Review, 20(3), 709-734.

Neuman, W. L. (2011). Social Research Methods: Qualitative and Quantitative Approaches (seventh). Edinburgh: Pearson Education Limited.

Paqih, K. M. S. (2011). Integrating Perceived Risk and Trust with Technology Acceptance Model: An Empirical Assessment of Customers ' Acceptance of Online Shopping in Jordan. 2011 International Conference on Research and Innovation in Information Systems, 1-5. IEEE.

Pavlou, P. A. (2003). Consumer Acceptance of Electronic Commerce: Integrating Trust and Risk with the Technology Acceptance Model. International Journal of Electronic Commerce, 7(3), 69-103.

Phatthana, W., \& Mat, N. K. N. (2011). The Application of Technology Acceptance Model ( TAM ) on health tourism epurchase intention predictors in Thailand. 2010 International Conference on Business and Economics Research, 1, 196-199.

Rana, N., Dwivedi, Y., Percy, N., \& Williams, M. (2014). Measuring Intention To Use And Satisfaction With Electronic District System: Validation of A Combined Model Of IS Success. UK Academy for Information Systems Conference Proceedings.

Roy, S. (2017). APP ADOPTION AND SWITCHING BEHAVIOR: APPLYING THE EXTENDED TAM IN SMARTPHONE APP USAGE. Journal of Information Systems and Technology Management, 14(2), 239261. https://doi.org/10.4301/S180717752017000200006

Sharma, S. K., \& Sharma, M. (2019). Examining the role of trust and quality dimensions in the actual usage of mobile banking services: An empirical investigation. International Journal of Information Management, 44, 65-75.

Siregar, S. (2013). Metode Penelitian Kuantitatif: Dilengkapi dengan Perbandingan Perhitungan Manual dan SPSS. Jakarta: Kencana Prenada Media Group.

Syahrum, \& Salim. (2012). METODOLOGI 
PENELITIAN KUANTITATIF (p. 176). p. 176.

Thakur, K. K., \& Banik, G. G. (2018). Cryptocurrency : Its Risks And Gains And The Way Ahead. IOSR Journal of Economics and Finance, 9(2), 38-42. https://doi.org/10.9790/59330902013842

Venkatesh, V., Aloysius, J., Hoehle, H., \& Burton, S. (2017). Design and Evaluation of AutoID Enabled Shopping Assistance Artifacts: Two Retail Store Laboratory Experiments. MIS Quarterly, 41(1), 83-113. Retrieved from http://www.vvenkatesh.com/wpcontent/uploads/dlm_uploads/2015/11/ Venkatesh-et-al.-MISQ-20172.pdf

Weng, F., Yang, R., Ho, H., \& Su, H. (2018). A TAM-Based Study of the Attitude towards Use Intention of Multimedia among
School Teachers. Applied System

Innovation, 1(3), 36.

https://doi.org/10.3390/asi1030036

Wu, B., \& Chen, X. (2017). Continuance intention to use MOOCs: Integrating the technology acceptance model (TAM) and task technology fit (TTF) model. Computers in Human Behavior, 67, 221232. https://doi.org/10.1016/j.chb.2016.10.02 8

Xie, Q., Song, W., Peng, X., \& Shabbir, M. (2017). Predictors for e-government adoption : integrating TAM , TPB , trust and perceived risk. The Electronic Library, 35(1), 2-20. https://doi.org/10.1108/EL08-2015-0141 